\title{
PENGAMANAN CITRA DIGITAL BERDASARKAN MODIFIKASI ALGORITMA RC4
}

\author{
Taronisokhi Zebua ${ }^{1}$, Eferoni Ndruru ${ }^{2}$ \\ ${ }^{1}$ AMIK STIEKOM Sumatera Utara \\ ${ }^{2}$ STMIK Budi Darma Medan \\ Email: ${ }^{1}$ taronizeb@gmail.com, ${ }^{2}$ ronindruru@gmail.com
}

(Naskah masuk: 9 Oktober 2017, diterima untuk diterbitkan: 24 Desember 2017)

\begin{abstract}
Abstrak
Citra digital yang bersifat pribadi dan rahasia sangat rentang terhadap penyadapan oleh pihak-pihak lain, terutama bila citra tersebut didistribusikan melalui internet. Tindakan penyadapan dan penyalahgunaan terhadap citra yang sifatnya rahasia tentu saja dapat merugikan pihak pemilik citra. Salah satu teknik untuk meminimalkan tindakan tersebut di atas adalah pemanfaatan teknik kriptografi. Teknik kriptografi dapat mengamankan citra digital dengan cara modifikasi nilai-nilai pixel citra sehingga citra yang dihasilkan berbeda dengan citra asli. Algoritma RC4 dapat digunakan sebagai salah satu algoritma dalam mewujudkan tujuan teknik kriptografi. Namun algoritma ini memiliki kelemahan di mana pemecahan algoritma ini dengan know plaintext attack atau know ciphertext only dapat dilakukan dengan mudah. Penelitian ini menguraikan pengamanan citra digital berdasarkan modifikasi algoritma RC4. Modifikasi yang dilakukan adalah menambahkan sebuah blok intial vector pada proses enkripsi maupun dekripsi serta melakukan pemindahan sejumlah bit pada posisi tertentu. Hasil penelitian ini adalah citra digital dengan nilai-nilai pixel yang jauh berbeda dengan nilai pixel aslinya dengan tujuan dapat mempersulit pihak lain dalam memanipulasi citra rahasia.
\end{abstract}

Kata kunci: kriptografi, citra, algoritma, RC4, cipher aliran.

\begin{abstract}
Digital images of a private and confidential verry extend to wiretapping by other parties, especially when the image is distributed over the internet. The tapping or misuse of the confidential private image of course, harm the image owner. One technique to minimize the above measures is the utilization of cryptographic techniques. Cryptography techniques can secure digital images by modifying the image pixel values so that the resulting image is different from the original image. RC4 algorithm can be used in realizing the purpose of cryptographic technique. But this algorithm has a weakness where the solving of this algorithm with know plaintext attack or know ciphertext only can be done easily. This research describes the security of digital images based on RC4 algorithm modification. The modification is to add a initial vector block in the process of encryption and decryption and shift a number of bits in a certain position. The results of this research is a digital image with pixel values that are much different from the original pixel value to make it difficult for others in manipulating the secret image.
\end{abstract}

Keywords: cryptography, image, algorithm, RC4, stream cipher.

\section{PENDAHULUAN}

Citra digital merupakan salah satu jenis data yang saat ini banyak digunakan dalam berkomunikasi baik secara langsung, maupun melalui media internet. Perkembangan pemanfaatan media sosial saat ini sudah semakin memudahkan orang-orang untuk saling berkomunikasi, bertukar informasi atau bertukar pesan baik berjenis teks, citra, audio maupun video. Namun, pada sisi lain pekermbangan tersebut menyebabkan semakin mudahnya pihak-pihak tertentu untuk melakukan penyerangan dan penyalahgunaan terhadap data-data atau informasi yang didistribusikan seperti tindakan penyadapan informasi, pemantauan informasi, manipulasi informasi atau menggunakan informasi tersebut pada kepentingan tertentu.

Berdasarkan penelitian Setianingsih, dalam penyandian citra sangat diperlukan sistem pengamanan untuk melindungi data yang ditransmisikan melalui suatu jaringan komunikasi. Salah satu cara yang dapat dilakukan untuk mengamankan data adalah dengan teknik kriptografi (Setyaningsih E., 2009). Sedangkan penelitian lain oleh Zebua dalam menyandikan record database mengatakan bahwa informasi penting untuk di jaga agar tidak dapat di akses dan disalahgunakan oleh orang-orang yang tidak berhak (Zebua T., 2013).

Salah satu algoritma kriptografi yang umum digunakan adalah algoritma RC4 (Rivest Cipher 4), namun kelemahan algoritma ini adalah mudah di serang dengan teknik know-plaintext attack dan 
ciphertext-only attack (Hendarsyah D. \& Wardoyo R., 2011).

Modifikasi algoritma RC4 yang diuraikan dalam penelitian ini adalah menambahkan sebuah nilai intialization vector (inisialisasi awal) yang saling berantai pada setiap operasi XOR antara biner pixel citra dan biner kunci serta melakukan pemindahan sejumlah bit-bit plain pada posisi tertentu baik pada proses enkripsi maupun pada proses dekripsi.

\section{CITRA DIGITAL}

Istilah lain dari gambar adalah citra digital dan merupakan bagian dari komponen multimedia yang sangat penting peranannya dalam menghasilkan informasi visual (Munir R., 2004). Gambar atau citra digital kaya dengan informasi sehingga karakteristik inilah yang membedakannya dengan teks. Citra di bagi menjadi dua jenis yaitu citra kotinu dan citra diskrit. Citra yang dihasilkan melalui proses digitalisasi terhadap citra kontinu di sebut dengan citra diskrit atau citra digital (digital image).

Citra digital tediri dari tiga jenis yaitu citra monocrome (hitam putih/citra biner), citra grayscale (abu-abu) dan citra true color (citra berwarna). Setiap pixel citra berwarna memiliki tiga elemen warna yang diistilahkan dengan RGB, yaitu Red (merah), Green (hijau) dan Blue (biru).

\section{KRIPTOGRAFI}

Teknik kriptografi merupakan salah satu teknik pengamanan data dengan melakukan proses penyandian terhadap data yang ingin diamankan sehingga makna asli dari data tidak lagi dapat dimengerti. Kriptografi merupakan salah satu teknik yang dapat digunakan dalam menjaga dan mengamankan informasi pada saat di distribusikan dari suatu tempat ke tempat lain (Ariyus D., 2008).

Adapun aspek atau tujuan yang harus dicapai dalam menerapkan teknik kriptografi adalah kerahasiaan, integritas, otentikasi dan nirpenyangkalan (Zebua T., 2015). Teknik kriptografi memiliki banyak algoritma dalam mencapai tujuan di atas, di antaranya algoritma hill cipher, affine cipher, DES, GOST, RC2, RC4 dan lainnya.

\section{ALGORITMA RC4}

Algoritma RC4 (Riverst Cipher 4) merupakan stream cipher yang dirancang di RSA Security oleh Ron Rivest tahun 1987. Sifat kunci dalam algoritma RC4 adalah simetris serta melakukan proses enkripsi plain per digit atau byte per byte dengan operasi biner (biasanya XOR) dengan sebuah angka semiacak. Namun algoritma ini memiliki kelemahan yaitu mudah diserang dengan teknik know-plaintext attack dan ciphertext-only attack (Setianingsih E., 2015). Serangan know-plaintext attack bisa diartikan jika kriptanalist memiliki potongan plaintext dan ciphertext, maka dengan mudah didapatkan aliran kunci dengan cara meng-XOR-kan plaintext dengan ciphertext.

Algortima RC4 bekerja dengan tiga tahap utama yaitu Key Scheduling Algorithm (KSA), Pseudo Random Generation Algorithm (PRGA) dan Proses Enkripsi dan Dekripsi (Setianingsih E., 2015) dan (Agung H. \& Budiman, 2015). Proses di atas, dapat diperlihatkan pada Gambar 1 di bawah ini.

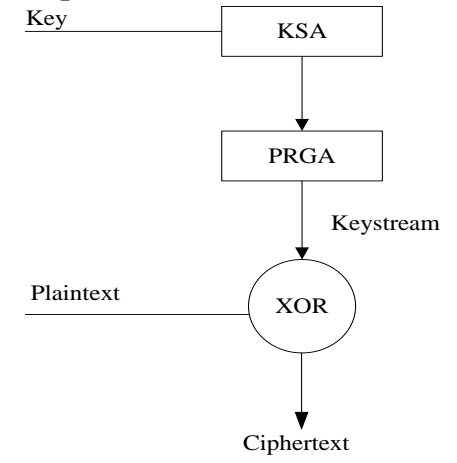

Gambar 1. Blok Diagaram Algoritma RC4

a. Key Scheduling Algorithm (KSA)

Proses KSA merupakan proses pembentukan tabel S-Box (Tabel Array S) dan Kunci (Tabel array [T]) yang di permutasi sebanyak 256 iterasi. Pseudocode untuk proses inisialisasi S-Box dan Array T:

$$
\begin{aligned}
& \text { for }(\mathrm{i}=0 ; \mathrm{i}<=255 ; \mathrm{i}++)\{ \\
& \quad \mathrm{S}-\mathrm{Box}[\mathrm{i}]=\mathrm{i} \\
& \mathrm{T}[\mathrm{i}]=\mathrm{kunci}[\mathrm{i} \text { mod panjang_kunci] } \\
& \text { \} }
\end{aligned}
$$

Pseudocode untuk permutasi isi array S-Box :

$$
\mathrm{j}=0
$$$$
\begin{aligned}
& \text { for }(i=0 ; i<=255 ; i++)\{ \\
& j=(j+S-B o x[i]+T[i]) \bmod 256 \\
& \quad \text { Swap }(S-B o x[i], S[j]) \\
& \quad j=j \\
& \quad
\end{aligned}
$$

setelah dua proses ini dilakukan, maka array S-Box dan array Kunci (T) telah terbentuk.

b. Pseudo Random Generation Algorithm (PRGA) Tabel array S-Box akan digunakan pada proses ini untuk menghasilkan key stream yang jumlahnya sama dengan jumlah banyaknya karakter plaintext kemudian akan di-XOR dengan plaintext. Adapun pseudocode proses PRGA ini adalah :

$$
\begin{aligned}
& \mathrm{i}=0 ; \mathrm{j}=\mathrm{i} \\
& \text { for }\left(\mathrm{i}=0 ; \mathrm{i}<=\mathrm{jlh} \_ \text {karakter_plaintext; } \mathrm{i}++\right)\{ \\
& \mathrm{i}=(\mathrm{i}+1) \bmod 256 \\
& \mathrm{j}=(\mathrm{j}+\mathrm{S}-\operatorname{Box}[\mathrm{i}]) \bmod 256 \\
& \text { Swap( S-Box[i], S-Box[j] ) } \\
& \mathrm{t}=(\mathrm{S}-\mathrm{Box}[\mathrm{i}]+\mathrm{S}-\mathrm{Box}[\mathrm{j}]) \bmod 256 \\
& \text { Kunci[i] }=\mathrm{S}-\mathrm{Box}[\mathrm{t}] \\
& \text { \} }
\end{aligned}
$$

c. Proses enkripsi atau dekripsi dengan operasi XOR. Proses enkripsi atau dekripsi di awali dengan merubah setiap nilai plaintext ke biner. 
Formula untuk melakukan proses enkripsi dan dekripsi (Zebua T., 2015), adalah:

Formula proses enkripsi:

$\mathrm{Ci}=\mathrm{Pi} \oplus \mathrm{Ki}$

Formula proses dekripsi:

$$
\mathrm{Pi}=\mathrm{Ci} \oplus \mathrm{Ki}
$$

\section{PEMBAHASAN}

Berdasarkan prosedur enkripsi dan dekripsi algoritma RC4, maka diketahui bahwa formulasi untuk melakukan proses enkripsi maupun dekripsi sangat sederhana, yaitu hanya dengan operasi XOR. Hal inilah yang menjadi salah satu kelemahan dari algoritma RC4 (Haji W. H. \& Mulyono S., 2012).

Modifikasi pada algoritma ini adalah menambahkan sebuah nilai inisialisasi awal yang kemudian di-XOR-kan dengan masing-masing plain atau cipher secara berantai untuk mengoptimalkan ketahanannya dari teknik penyerangan. Hasil operasi inilah yang kemudian di-XOR-kan dengan kunci. Cipher yang dihasilkan merupakan rangkaian bit yang telah teracak. Diagram proses modifikasi RC4 ditunjukkan pada Gambar 2.

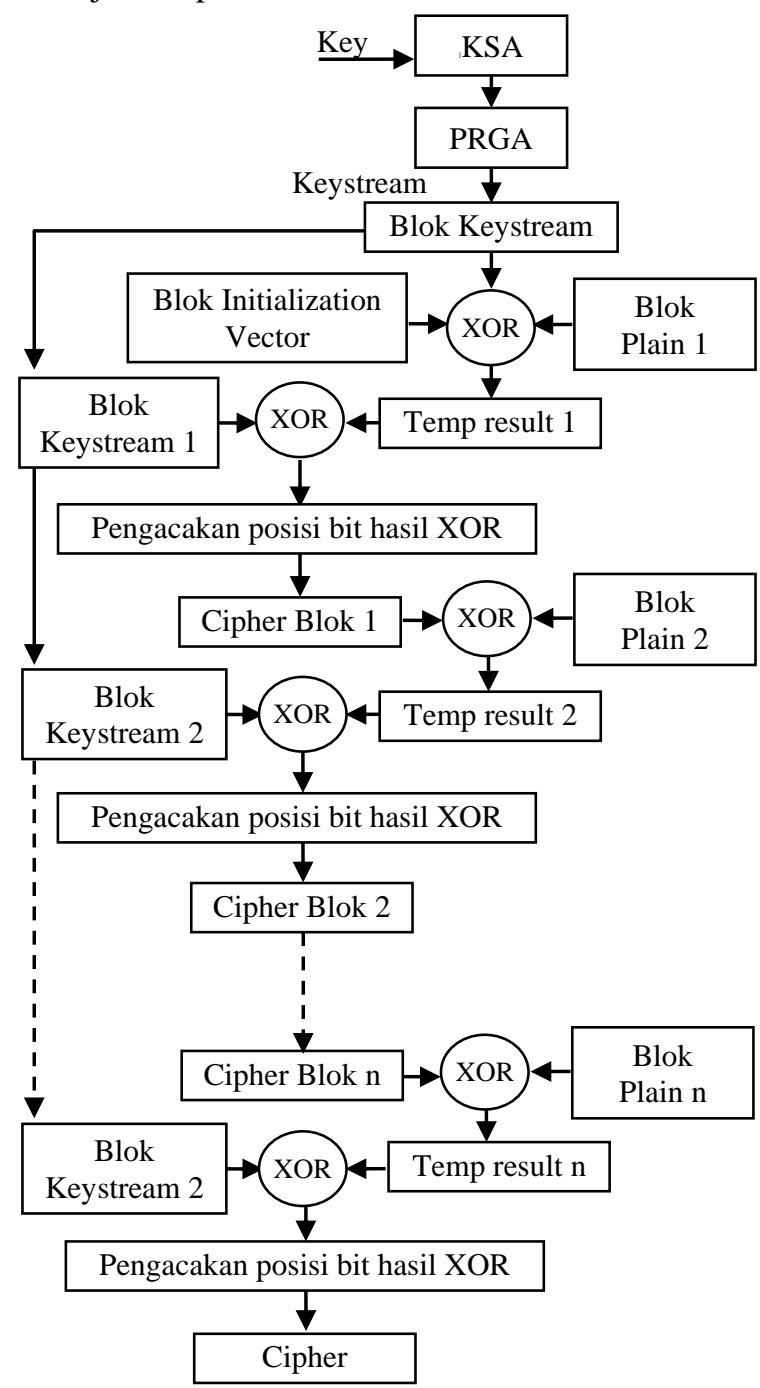

Gambar 2. Diagram Proses Modifikasi Algoritma RC4
Berdasarkan Gambar 2, dapat di ketahui bahwa setiap proses yang dilakukan untuk menghasilkan cipher berikutnya bergantung dari cipher sebelumnya.

Formulai enkripsi menjadi:

$$
\mathrm{C}[\mathrm{i}]=(\mathrm{P}[\mathrm{i}] \oplus \mathrm{C}[\mathrm{i}-1]) \oplus \mathrm{K}[\mathrm{i}+1]
$$

Formulai dekripsi menjadi :

$$
\mathrm{P}[\mathrm{i}]=(\mathrm{C}[\mathrm{i}] \oplus \mathrm{C}[\mathrm{i}-1]) \oplus \mathrm{K}[\mathrm{i}-1]
$$

di mana:

$\mathrm{P}[\mathrm{i}]$ adalah biner setiap blok plain

$\mathrm{C}[\mathrm{i}]$ adalah biner cipher setelah dikembalikan bitnya

$\mathrm{C}[\mathrm{i}-1]$ biner cipher sebelum dikembalikan bitnya (cipher asli)

$\mathrm{C}[0]$ adalah nilai Initialization Vector (IV)

$\mathrm{K}[\mathrm{i}+1]$ dan $\mathrm{K}[\mathrm{i}-1]$ adalah kunci

Proses dekripsi berdasarkan modifikasi algoritma RC4 ini di lakukan dengan cara yang sama seperti pada diagram proses enkripsi di atas.

Berikut ini diuraikan contoh penerapan algoritma RC4 yang telah di modifikasi dalam menyandikan sebuah citra berwarna berekstensi bmp dengan resolusi 187 x 314 dan bitdepth adalah 24 bit dengan kunci yang digunakan adalah ZEBUA dan biner Inisialization Vector adalah 01010100.

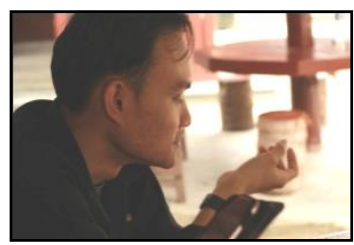

Gambar 4. Plainimage dengan Resolusi 187 x 314

Berdasarkan plainimage di atas, akan diambil 3 pixel sebagai sampel dalam perhitungan manual. Tiga pixel tersebut akan di ambil nilai desimal warna pada setiap elemen warna pixelnya.

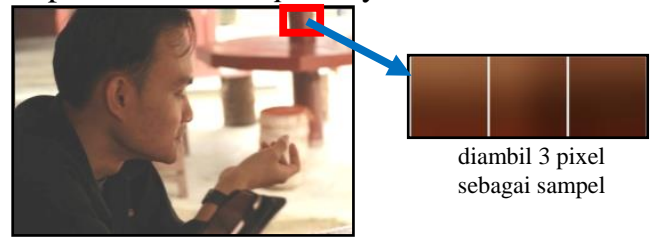

Gambar 5. Plainimage Sampel sebanyak 3 Pixel

Nilai elemen warna dari tiga pixel plainimage sampel di atas di ambil dengan menggunakan software matlab, sehingga diperoleh:

Tabel 1. Nilai RGB Citra Sampel

\begin{tabular}{ccccccccc}
\hline \multicolumn{3}{c}{ Pixel 1 } & \multicolumn{3}{c}{ Pixel 2 } & \multicolumn{3}{c}{ Pixel 3 } \\
\hline R & G & B & R & G & B & R & G & B \\
\hline 154 & 96 & 60 & 113 & 59 & 33 & 71 & 26 & 28 \\
\hline
\end{tabular}

Berdasarkan Tabel 1 di atas, maka nilai desimal plainimage adalah 154,96,60,133, 59, 33, 71, 26, 28. 


\subsection{Proses Enkripsi}

Proses enkripsi berdasarkan modifikasi algoritma RC4, meliputi:

a. Proses Key Scheduling Algorithm (KSA)

Pembentukan Tabel S-Box, dilakukan berdasaran pseudocode-nya dan menghasilkan array dengan nilai 0 sampai dengan 255, sehingga tabel S-Box :

Tabel 2. Tabel S-Box

\begin{tabular}{|c|c|c|c|c|c|c|c|c|c|c|c|c|c|c|c|}
\hline 0 & 1 & 2 & 3 & 4 & 5 & 6 & 7 & 8 & 9 & 10 & 11 & 12 & 13 & 14 & 15 \\
\hline 16 & 17 & 18 & 19 & 20 & 21 & 22 & 23 & 24 & 25 & 26 & 27 & 28 & 29 & 30 & 31 \\
\hline$:$ & $:$ & : & & & & & & & & & & $\begin{array}{l}: \\
: \\
:\end{array}$ & \begin{tabular}{|l} 
\\
$\vdots$ \\
$\vdots$
\end{tabular} & $\begin{array}{l}: \\
:\end{array}$ & \\
\hline & & & & & & & & & & & & & & 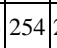 & 55 \\
\hline
\end{tabular}

Karakter kunci di buat dalam bentuk array :

\begin{tabular}{|c|c|c|c|c|}
\hline Index0 & Index1 & Index2 & Index3 & Index4 \\
\hline $\mathrm{Z}$ & $\mathrm{E}$ & $\mathrm{B}$ & $\mathrm{U}$ & $\mathrm{A}$ \\
\hline
\end{tabular}

Kemudian bentuklah array Tabel T sesuai dengan pseudocode-nya :

untuk $\mathrm{i}=0$

$\mathrm{T}[0]=\operatorname{Kunci}[0 \bmod 5]$

$\mathrm{T}[0]=\operatorname{Kunci}[0] \rightarrow \mathrm{Z}(\mathrm{dec} 90)$

untuk $\mathrm{i}=1$

$\mathrm{T}[1]=\mathrm{Kunci}[1 \bmod 5]$

$\mathrm{T}[1]=\operatorname{Kunci}[1] \rightarrow \mathrm{E}(\operatorname{dec} 69)$

proses ini dilakukan hingga nilai $\mathrm{i}=255$

untuk $\mathrm{i}=255$

$$
\begin{aligned}
& \mathrm{T}[255]=\operatorname{Kunci}[255 \bmod 5] \\
& \mathrm{T}[255]=\text { Kunci[0] } \rightarrow \mathrm{Z}(\operatorname{dec} 90)
\end{aligned}
$$

Sehingga dihasilkan nilai tabel $\mathrm{T}$ keseluruhan adalah :

Tabel 3 : Tabel Array T

\begin{tabular}{|c|c|c|c|c|c|c|c|c|c|c|c|c|c|c|c|}
\hline 90 & 69 & 66 & 85 & 65 & 90 & 69 & 66 & 85 & 65 & 90 & 69 & 66 & 85 & 65 & 90 \\
\hline 69 & 66 & 85 & 65 & 90 & 69 & 66 & 85 & 65 & 90 & 69 & 66 & 85 & 65 & 90 & 69 \\
\hline$\vdots$ & $\vdots$ & $\vdots$ & $\vdots$ & $\vdots$ & $\vdots$ & $\vdots$ & $\vdots$ & $\vdots$ & $\vdots$ & $\vdots$ & $\vdots$ & $\vdots$ & $\vdots$ & $\vdots$ & $\vdots$ \\
$\vdots$ & $\vdots$ & $\vdots$ & $\vdots$ & $\vdots$ & $\vdots$ & $\vdots$ & $\vdots$ & $\vdots$ & $\vdots$ & $\vdots$ & $\vdots$ & $\vdots$ & $\vdots$ & $\vdots$ & $\vdots$ \\
$\vdots$ & $\vdots$ & $\vdots$ & $:$ & $:$ & $\vdots$ & $\vdots$ & $\vdots$ & $\vdots$ & $\vdots$ & $\vdots$ \\
\hline 90 & 69 & 66 & 85 & 65 & 90 & 69 & 66 & 85 & 65 & 90 & 69 & 66 & 85 & 65 & 90 \\
\hline
\end{tabular}

Setelah tabel array S-Box dan Array $\mathrm{T}$ di dapatkan, maka langkah selanjutnya adalah melakukan permutasi nilai-nilai tabel array S-Box. Permutasi dilakukan sebanyak 256 kali iterasi dengan menukarkan nilai S-Box dalam array i dengan nilai S-Box pada array j.

$$
\begin{aligned}
& \text { untuk nilai } \mathrm{i}=0 ; \mathrm{j}=0 \\
& \mathrm{j}=(0+\mathrm{S}-\mathrm{Box}[0]+\mathrm{T}[0]) \bmod 256 \\
& \mathrm{j}=(0+0+90) \bmod 256 \\
& \mathrm{j}=90 \\
& \text { Swap(S-Box[0], S-Box[90]) } \\
& \mathrm{j}=90 \text {, nilai } \mathrm{j} \text { berikutnya adalah } 90
\end{aligned}
$$

Tukarkan nilai tabel S-Box pada array 0 dengan nilai tabel S-Box pada array 90 dan begitu sebaliknya.
Berdasarkan tabel 2, maka nilai S-Box[0] $=0$ dan nilai $\mathrm{S}-\mathrm{Box}[90]=90$. Jadi setelah ditukarkan, maka nilai S-Box[0] $=90$ dan S-Box[90] $=0$.

untuk nilai $\mathrm{i}=1 ; \mathrm{j}=90$ (nilai akhir $\mathrm{j}$ pada iterasi $\mathrm{i}=0$ )

$\mathrm{j}=(90+\mathrm{S}-\mathrm{Box}[1]+\mathrm{T}[1]) \bmod 256$

$\mathrm{j}=(90+1+69) \bmod 256$

$\mathrm{j}=160 \bmod 256=160$

Swap(S-Box[1], S-Box[160])

$\mathrm{j}=90$, nilai $\mathrm{j}$ berikutnya adalah 90

Tukarkan nilai tabel S-Box pada array 1 (nilai i) dengan nilai tabel S-Box pada array 160 (nilai j) dan begitu sebaliknya.

Berdasarkan Tabel 2 setelah proses permutasi sebelumnya, maka nilai $\mathrm{S}-\operatorname{Box}[1]=1$ dan nilai S-Box $[160]=160$. Jadi setelah ditukarkan, maka nilai S-Box[1] = 160 dan S-Box[160] = 1 .

Pada proses permutasi ini, nilai tabel S-Box yang digunakan pada setiap proses swap (penukaran) adalah nilai S-Box setelah dipermutasikan.

Proses permutasi ini dilakukan hingga nilai $\mathrm{i}=255$, sehingga proses ini dapat menyebabkan nilai array S-Box dapat di tukar secara berulang atau lebih dari satu kali. Hasil proses permutasi Tabel S-Box keseluruhan adalah:

Tabel 4. Hasil Permutasi S-Box

\begin{tabular}{|l|l|l|l|l|l|l|l|l|l|l|l|l|l|l|}
\hline 90 & 160 & 239 & 60 & 129 & 49 & 218 & 141 & 20 & 53 & 127 & 207 & 29 & 125 & 85 \\
\hline 5 & 176 & 246 & 02 & 154 & 40 & 107 & 186 & 34 & 13 & 72 & 133 & 63 & 201 & 0 \\
\hline
\end{tabular} \begin{tabular}{|l|l|l|l|l|l|l|l|l|l|l|l|l|l|l|}
\hline 55 & 176 & 246 & 102 & 154 & 40 & 107 & 186 & 34 & 13 & 72 & 133 & 63 & 201 & 0 \\
\hline
\end{tabular} \begin{tabular}{|l|l|l|l|l|l|l|l|l|l|l|l|l|l|l|}
\hline 159 & 54 & 79 & 206 & 113 & 238 & 87 & 190 & 78 & 146 & 41 & 71 & 58 & 31 & 163 \\
\hline
\end{tabular}

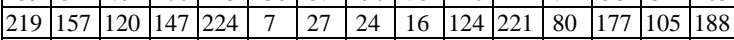
\begin{tabular}{|l|l|l|l|l|l|l|l|l|l|l|l|l|l|l|}
\hline 191 & 155 & 158 & 175 & 187 & 197 & 76 & 48 & 106 & 151 & 52 & 232 & 30 & 140 & 253 \\
\hline
\end{tabular} \begin{tabular}{|l|l|l|l|l|l|l|l|l|l|l|l|l|l|l|}
\hline 46 & 59 & 86 & 91 & 137 & 9 & 131 & 108 & 132 & 93 & 200 & 12 & 222 & 109 & 116 \\
\hline
\end{tabular}

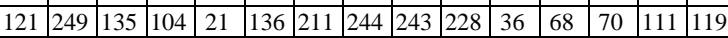
\begin{tabular}{|l|l|l|l|l|l|l|l|l|l|l|l|l|l|l|}
\hline 150 & 2 & 166 & 220 & 138 & 88 & 189 & 84 & 144 & 112 & 230 & 139 & 6 & 212 & 3 \\
\hline
\end{tabular} \begin{tabular}{|c|c|c|c|c|c|c|c|c|c|c|c|c|c|c|}
\hline 95 & 195 & 250 & 183 & 56 & 28 & 208 & 92 & 165 & 164 & 196 & 171 & 75 & 122 & 225 \\
\hline
\end{tabular} \begin{tabular}{|l|l|l|l|l|l|l|l|l|l|l|l|l|l|l|}
\hline 173 & 143 & 254 & 100 & 57 & 51 & 74 & 215 & 18 & 38 & 19 & 178 & 22 & 181 & 153 \\
\hline 134 & 248 & 167 & 204 & 117 & 89 & 148 & 45 & 56 & 236 & 231 & 69 & 110 & 23 & 14 \\
\hline
\end{tabular} \begin{tabular}{llll|l|l|l|l|l|l|l|l|l|l|l|l|}
134 & 248 & 167 & 204 & 117 & 89 & 148 & 45 & 156 & 236 & 231 & 69 & 110 & 23 & 114 \\
\hline
\end{tabular} \begin{tabular}{|l|l|l|l|l|l|l|l|l|l|l|l|l|l|l|}
\hline 62 & 50 & 205 & 202 & 81 & 152 & 96 & 25 & 97 & 227 & 128 & 73 & 203 & 26 & 229 \\
\hline 66 & 193 & 184 & 214 & 37 & 103 & 251 & 83 & 234 & 226 & 5 & 101 & 255 & 44 & 162 \\
\hline
\end{tabular} \begin{tabular}{|l|l|l|l|l|l|l|l|l|l|l|l|l|l|l|}
\hline 66 & 193 & 184 & 214 & 37 & 103 & 251 & 83 & 234 & 226 & 5 & 101 & 255 & 44 & 162 \\
\hline
\end{tabular} \begin{tabular}{|c|c|c|c|c|c|c|c|c|c|c|c|c|c|c|}
\hline 1 & 77 & 237 & 64 & 161 & 47 & 10 & 43 & 115 & 94 & 235 & 14 & 126 & 67 & 199 \\
\hline
\end{tabular}

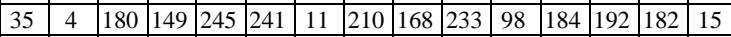
\begin{tabular}{|l|l|l|l|l|l|l|l|l|l|l|l|l|l|l|}
\hline 198 & 17 & 209 & 242 & 118 & 145 & 213 & 130 & 82 & 216 & 179 & 142 & 174 & 39 & 99 \\
\hline
\end{tabular} \begin{tabular}{|l|l|l|l|l|l|l|l|l|l|l|l|l|l|l|}
\hline 172 & 217 & 33 & 123 & 194 & 65 & 233 & 61 & 252 & 42 & 169 & 8 & 240 & 247 & 190 \\
\hline
\end{tabular}

\section{b. Pseudo Random Generation Algorithm (PRGA)}

Proses PRGA menggunakan hasil permutasi S-Box pada Tabel 4 di atas. Proses ini dilakukan untuk menghasilkan key stream yang akan digunakan pada proses enkripsi ataupun dekripsi.

Proses iterasi pada PRGA dilakukan sebanyak jumlah nilai-nilai elemen warna citra. Bila citra sampel yang digunakan di atas memiliki 9 nilai, maka iterasi proses PRGA akan di lakukan sebanyak 9 kali.

Pada Proses PRGA menyebabkan tabel permutasi S-Box akan dipermutasikan kembali sebanyak iterasi yang dilakukan pada proses ini. 
untuk iterasi $1 \rightarrow \mathrm{i}=0 ; \mathrm{j}=\mathrm{i}$

$\mathrm{i}=(0+1) \bmod 256=1$

$\mathrm{j}=(0+\mathrm{S}-\mathrm{Box}[1]) \bmod 256$

$\mathrm{j}=(0+90) \bmod 256$

$\mathrm{j}=90$

Swap (S-Box[1], S-Box[90])

Berdasarkan tabel hasil permutasi S-Box (tabel 4), maka nilai $\mathrm{S}-\operatorname{Box}[1]=160$; S-Box[90] = 116

setelah ditukarkan menjadi :

S-Box $[0]=116 ;$ S-Box $[90]=160$

$\mathrm{t}=(\mathrm{S}-\mathrm{Box}[1]+\mathrm{S}-\mathrm{Box}[90]) \bmod 256$

$\mathrm{t}=(116+160) \bmod 256$

$\mathrm{t}=276 \bmod 256$

$\mathrm{t}=20$

Kunci[0] $=$ S-Box[20] $\rightarrow 154($ char $\breve{s})$

untuk iterasi $2 \rightarrow \mathrm{i}=1 ; \mathrm{j}=1$

$\mathrm{i}=(1+1) \bmod 256=2$

$\mathrm{j}=(1+\mathrm{S}-\mathrm{Box}[2]) \bmod 256$

$\mathrm{j}=(1+239) \bmod 256$

$\mathrm{j}=240$

Swap (S-Box[2], S-Box[240])

Berdasarkan tabel S-Box (setelah permutasi iterasi 2 di atas), maka : nilai S-Box[2] $=239$ dan S-Box[240] = 99

setelah ditukarkan menjadi :

S-Box[2] = 99; S-Box[239] = 239

$\mathrm{t}=(\mathrm{S}-\mathrm{Box}[2]+\mathrm{S}-\mathrm{Box}[239]) \bmod 256$

$\mathrm{t}=(99+239) \bmod 256$

$\mathrm{t}=338 \bmod 256 ; \mathrm{t}=82$

Kunci[1] $=\operatorname{S-Box}[82] \rightarrow 131(\operatorname{char} f)$

Iterasi selanjutnya di cari berdasarkan cara yang sama seperti di atas, sehingga di peroleh hasil dari key stream seperti ditunjukkan pada Tabel 5.

Tabel 5. Hasil Pseudorandom Key

\begin{tabular}{ccc}
\hline Kunci & Desimal & Char \\
\hline $\mathrm{K}[0]$ & 154 & $\breve{\mathrm{S}}$ \\
$\mathrm{K}[1]$ & 131 & $\mathrm{~F}$ \\
$\mathrm{~K}[2]$ & 107 & $\times$ \\
$\mathrm{K}[3]$ & 31 & \\
$\mathrm{~K}[4]$ & 151 & - \\
$\mathrm{K}[5]$ & 204 & $\grave{\mathrm{I}}$ \\
$\mathrm{K}[6]$ & 141 & $\mathrm{R}$ \\
$\mathrm{K}[7]$ & 167 & $\S$ \\
$\mathrm{K}[8]$ & 123 & \{ \\
\hline
\end{tabular}

key stream yang dihasilkan dari proses PRGA di atas akan digunakan sebagai kunci pada proses enkripsi maupun dekripsi.

\begin{tabular}{|c|c|c|c|c|c|c|}
\hline Kunci & Char & $\mathrm{Z}$ & $\mathrm{E}$ & $\mathrm{B}$ & $\mathrm{U}$ & $\mathrm{A}$ \\
\cline { 2 - 7 } Awal & Dec & 90 & 69 & 66 & 85 & 65 \\
\hline
\end{tabular}

\begin{tabular}{|c|c|c|c|c|c|c|c|c|c|c|}
\hline Key & Char & $\breve{s}$ & $f$ & $\times$ & & - & I & r & $\S$ & \{ \\
\cline { 2 - 9 } Stream & Dec & 154 & 131 & 107 & 31 & 151 & 204 & 141 & 167 & 123 \\
\hline
\end{tabular}

Berdasarkan jumlah key stream yang dihasilkan di atas, maka disimpulkan bahwa jumlah key stream yang dibangkitkan berbanding lurus atau sama dengan jumlah banyaknya pixel citra digital yang akan disandikan. Hal ini terjadi karena RC4 mengenkripsi setiap pixel citra dengan kunci yang berbeda. Konsep ini hampir sama dengan konsep algoritma vegeneere cipher.

c. Proses Enkripsi

Proses enkripsi di awali dengan mengkonversi nilai-nilai warna elemen pixel citra ke bilangan biner. Hal yang sama juga dilakukan untuk karakter key stream.

Tabel 6. Hasil konversi nilai pixel citra ke biner

\begin{tabular}{ccccc}
\hline Pixel & Warna & Dec & Biner & P[i] \\
\hline \multirow{3}{*}{1} & R & 154 & 10011010 & $\mathrm{P}[1]$ \\
& G & 96 & 01100000 & $\mathrm{P}[2]$ \\
& $\mathrm{B}$ & 60 & 00111100 & $\mathrm{P}[3]$ \\
& $\mathrm{R}$ & 133 & 10000101 & $\mathrm{P}[4]$ \\
2 & $\mathrm{G}$ & 59 & 00111011 & $\mathrm{P}[5]$ \\
& $\mathrm{B}$ & 33 & 00100001 & $\mathrm{P}[6]$ \\
& $\mathrm{R}$ & 71 & 01000111 & $\mathrm{P}[7]$ \\
3 & $\mathrm{G}$ & 26 & 00011010 & $\mathrm{P}[8]$ \\
& $\mathrm{B}$ & 28 & 00011100 & $\mathrm{P}[9]$ \\
\hline
\end{tabular}

Tabel 7. Hasil Konversi Key Stream Ke Biner

\begin{tabular}{crcl}
\hline Key & Char & Dec & Biner \\
\hline K[0] & $\check{S}$ & 154 & 10011010 \\
K[1] & F & 131 & 10000011 \\
K[2] & $\times$ & 107 & 01101011 \\
K[3] & & 31 & 00011111 \\
K[4] & - & 151 & 10010111 \\
K[5] & $\grave{I}$ & 204 & 11001100 \\
K[6] & R & 141 & 10001101 \\
K[7] & $\S$ & 167 & 10100111 \\
K[8] & \{ & 123 & 01111011
\end{tabular}

Selanjutnya melakukan proses enkripsi berdasarkan Persamaan (3).

Nilai bit Inisialization Vector (IV) atau C0 : 01010100

Karena jumlah bit IV adalah 8 bit, maka binerbiner plainimage dikelompokkan menjadi 8 bit (seperti kolom Pi pada Tabel 6). 
Enkripsi Blok P1 : $i=1$

$\mathrm{C} 1=(\mathrm{P}[1] \oplus \mathrm{C}[1-1]) \oplus \mathrm{K}[1-1]$

$=(\mathrm{P}[1] \oplus \mathrm{C}[0]) \oplus \mathrm{K}[0]$

$=(10011010 \oplus 01010100) \oplus 10011010$

$=11001110 \oplus 10011010$

$=01010100$

Shift 2 bit dari kiri ke kanan (pemindahan 2 bit kiri ke kanan )

$\mathrm{C} 1=01010001(\operatorname{dec} \mathbf{8 1})$

Enkripsi Blok P2 : $i=2$

$$
\begin{aligned}
\mathrm{C} 2 & =(\mathrm{P}[2] \oplus \mathrm{C}[2-1]) \oplus \mathrm{K}[2-1] \\
& =(\mathrm{P}[2] \oplus \mathrm{C}[1]) \oplus \mathrm{K}[1] \\
& =(01100000 \oplus 01010001) \oplus 10000011 \\
& =00110001 \oplus 10000011 \\
& =10110010
\end{aligned}
$$

Shift 2 bit dari kiri ke kanan (pemindahan 2 bit kiri ke kanan )

$$
\mathrm{C} 2=11001010(\operatorname{dec} 202)
$$

Proses yang sama dilakukan untuk mencari Cipher dari blok plainimage lainnya, sehingga cipher seluruhnya seperti pada Tabel 8.

\begin{tabular}{|c|c|c|c|}
\hline Pixel & Warna & $\frac{\text { Plain }}{\text { Dec }}$ & $\frac{\text { Cipher }}{\text { Dec }}$ \\
\hline \multirow{3}{*}{1} & $\mathrm{R}$ & 154 & 81 \\
\hline & G & 96 & 202 \\
\hline & B & 60 & 118 \\
\hline \multirow{3}{*}{2} & $\mathrm{R}$ & 133 & 179 \\
\hline & G & 59 & 124 \\
\hline & B & 33 & 70 \\
\hline \multirow{3}{*}{3} & $\mathrm{R}$ & 71 & 50 \\
\hline & G & 26 & 62 \\
\hline & B & 28 & 101 \\
\hline
\end{tabular}

Tabel 8. Nilai Desimal Hasil Enkripsi

\begin{tabular}{cc}
\hline Block Ci & Nilai Desimal \\
\hline C1 & 81 \\
C2 & 202 \\
C3 & 118 \\
C4 & 179 \\
C5 & 124 \\
C6 & 70 \\
C7 & 50 \\
C8 & 62 \\
C9 & 101 \\
\hline
\end{tabular}

Sehingga, nilai warna citra asli (plainimage) setelah di enkripsi dunjukkan pada Tabel 9.

Tabel 9. Nilai Pixel CipherImage

Sehingga, warna citra yang dihasilkan akibat perubahan nilai setiap elemen warna pixel plainimage adalah:

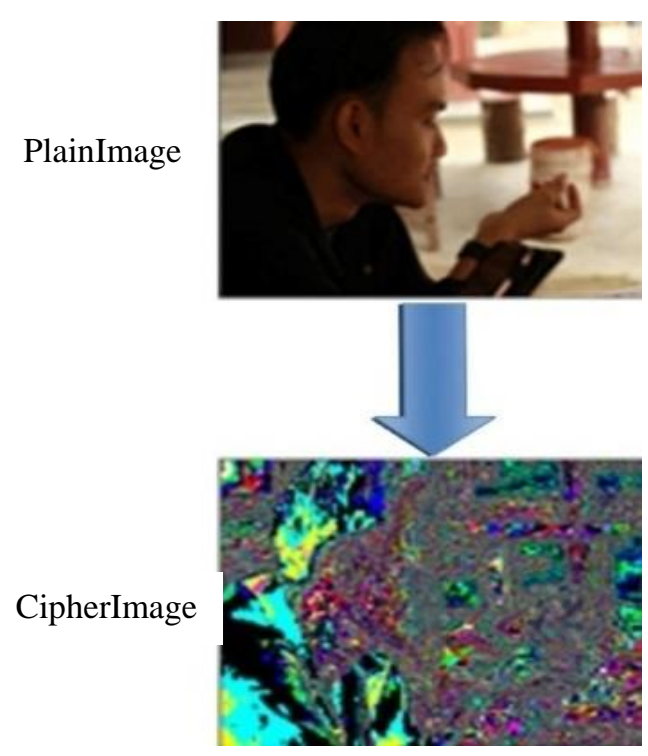

Gambar 6. Tampilan CipherImage

\subsection{Proses Dekripsi}

Proses dekripsi di awali dengan proses KSA dan proses PRNG. Prosesnya sama dengan yang dilakukan pada proses enkripsi. Sehingga key stream yang dihasilkan sama seperti key sream pada proses enkripsi (tabel 5).

Sebelum proses dekripsi dilakukan, cipherimage dan nilai-nilai karakter kunci sebagai input harus dikonversi menjadi biner, kemudian dilakukan pengelompokkan biner cipher sepanjang jumlah bit initialization vector (IV/C0).

Selanjutnya, dilakukan pengembalian 2 bit kanan ke posisi kiri pada setiap kelompok cipherimage. Hal dilakukan agar posisi-posisi bit yang telah di acak kembali pada posisi semula.

Tahap terakhir adalah melakukan proses dekripsi berdasarkan Persamaan (4).

Tabel 10. Nilai Desimal Pixel Cipher Image

\begin{tabular}{ccccc}
\hline Pixel & Warna & $\begin{array}{c}\text { Decimal } \\
\text { Pixel } \\
\text { Cipher }\end{array}$ & $\begin{array}{c}\text { BinerPixel } \\
\text { Cipher }\end{array}$ & Ci \\
\hline \multirow{3}{*}{1} & R & 81 & 01010001 & C[1] \\
& G & 202 & 11001010 & C[2] \\
& B & 118 & 01110110 & C[3] \\
& R & 179 & 10110011 & C[4] \\
& G & 124 & 01111100 & C[5] \\
& B & 70 & 01000110 & C[6] \\
& R & 50 & 00110010 & C[7] \\
& G & 62 & 00111110 & C[8] \\
& B & 101 & 01100101 & C[9] \\
\hline
\end{tabular}


Nilai key stream sama dengan nilai pada Tabel 7 . IV/C0 sama dengan nilai yang IV yang digunakan pada proses enkripsi yaitu 01010100. 2 bit di posisi kanan pada masing-masing kelompok cipherimage dikembalikan ke posisi kiri, sehingga di peroleh hasilnya seperti pada Tabel 11 .

Tabel 11. Hasil Pengembalian Bit CipherImage

\begin{tabular}{ccc}
\hline $\mathrm{Ci}$ & $\begin{array}{c}\text { BinerPixel Cipher } \\
\text { Sebelum dikembalikan }\end{array}$ & $\begin{array}{c}\text { BinerPixel Cipher } \\
\text { Setelah dikembalikan }\end{array}$ \\
\hline $\mathrm{C}[1]$ & 01010001 & 01010100 \\
$\mathrm{C}[2]$ & 11001010 & 10110010 \\
$\mathrm{C}[3]$ & 01110110 & 10011101 \\
$\mathrm{C}[4]$ & 10110011 & 11101100 \\
$\mathrm{C}[5]$ & 01111100 & 00011111 \\
$\mathrm{C}[6]$ & 01000110 & 10010001 \\
$\mathrm{C}[7]$ & 00110010 & 10001100 \\
$\mathrm{C}[8]$ & 00111110 & 10001111 \\
$\mathrm{C}[9]$ & 01100101 & 01011001 \\
\hline
\end{tabular}

untuk mencari PlainImage Blok $1: \mathrm{i}=1$

$$
\begin{aligned}
\mathrm{P}[1] & =(\mathrm{C}[1] \oplus \mathrm{C}[1-1]) \oplus \mathrm{K}[1-1] \\
& =(\mathrm{C}[1] \oplus \mathrm{C}[0]) \oplus \mathrm{K}[0] \\
& =(01010100 \oplus 01010100) \oplus 10011010 \\
& =00000101 \oplus 10011010 \\
\mathrm{P}[1] & =10011010 \text { (decimal 154) }
\end{aligned}
$$

Untuk mencari PlainImage Blok $2: i=2$

$$
\begin{aligned}
\mathrm{P}[2] & =(\mathrm{C}[2] \oplus \mathrm{C}[2-1]) \oplus \mathrm{K}[2-1] \\
& =(\mathrm{C}[2] \oplus \mathrm{C}[1]) \oplus \mathrm{K}[1] \\
& =(10110010 \oplus 01010001) \oplus 10000011 \\
& =11100011 \oplus 10000011 \\
\mathrm{P}[2] & =01100000(\text { decimal } 96)
\end{aligned}
$$

Untuk mencari PlainImage Blok $3: i=3$

$$
\begin{aligned}
\mathrm{P}[3] & =(\mathrm{C}[3] \oplus \mathrm{C}[3-1]) \oplus \mathrm{K}[3-1] \\
& =(\mathrm{C}[3] \oplus \mathrm{C}[2]) \oplus \mathrm{K}[2] \\
& =(10011101 \oplus 11001010) \oplus 01101011 \\
& =01010111 \oplus 01101011 \\
\mathrm{P}[3] & =00111100(\text { decimal } 60)
\end{aligned}
$$

untuk mendapatkan nilai pixel plainimage dari blok cipherimage lainnya dilakukan dengan cara yang sama seperti di atas. Nilai yang dihasilkan sama seperti nilai setiap elemen warna pixel citra asli.

\begin{tabular}{cccc}
\multicolumn{3}{c}{ Tabel 12. Nilai Pixel Citra Hasil Dekripsi } \\
\hline \multirow{2}{*}{ Pixel } & \multirow{2}{*}{ Warna } & Plain & $\begin{array}{c}\text { Blok } \\
\text { PlainImage }\end{array}$ \\
\cline { 3 - 4 } 1 & R & Dec & P[1] \\
& G & 96 & P[2] \\
& B & 60 & P[3] \\
2 & R & 133 & P[4] \\
& G & 59 & P[5] \\
& B & 33 & P[6] \\
3 & R & 71 & P[7] \\
& G & 26 & P[8] \\
& B & 28 & P[9]
\end{tabular}

Nilai-nilai elemen warna pixel citra tersebut di atas dipetakan kembali menjadi citra yang baru sehingga menghasilkan citra yang sama seperti citra aslinya (plainimage).

\subsection{Ketahanan Terhadap Know Plain dan Know Cipher Attack}

Jenis serangan know plain attack maupun know cipher attack dapat dilakukan dengan mengetahui potongan-potongan dari plain dan cipher kemudian kedua potongan tersebut di-XOR-kan untuk mendapatkan aliran kunci yang digunakan.

Bila seorang kriptanalis berhasil mendapatkan potongan biner plain dan cipher data yang telah di enkripsi berdasarkan algoritma RC4 tanpa modifikasi, kemudian dilakukan operasi XOR.

potongan biner plain $\quad=10011001$

potongan biner cipher $=\underline{11001001} \oplus$

maka, kunci adalah $=01010000$

Bila potongan biner plain maupun cipher di-XORkan dengan kunci yang telah ditemukan, maka cipher atau plain adalah benar.

potongan biner plain $\quad=10011001$

potongan biner kunci $=\underline{01010000} \oplus$

maka, cipher adalah $=11001001$

hasil operasi XOR yang didapatkan sama dengan biner cipher.

Ketahanan data yang telah di enkripsi berdasarkan modifikasi algoritma RC4 terhadap serangan jenis know plain dan know cipher terletak pada rumitnya untuk menemukan aliran kunci yang digunakan baik pada proses enkripsi maupun dekripsi. Kekuatan RC4 termodifikasi terletak pada operasi XOR yang tidak hanya dilakukan dengan kunci, namun dilakukan pada blok biner inisialisasi serta adanya proses pemindahan sejumlah bit dari posisi kiri ke kanan untuk mengacak posisi-posisi biner hasil operasi XOR dan proses ini dilakukan secara berantai pada setiap blok plain maupun cipher.

\section{KESIMPULAN}

Berdasarkan pembahasan di atas, maka disimpulkan bahwa :

1. Penambahan blok initialization vector dan pergeseran bit pada proses enkripsi maupun dekripsi pada modifikasi algoritma RC4 sangat efektif untuk mempersulit pihak penyerang baik dengan cara know plain attack maupun cipheronly attack.

2. Modifikasi yang dilakukan pada algoritma RC4 ini sangat efektif dalam mengaburkan pola dan warna citra asli sehingga cipherimage yang dihasilkan sangat berbeda dengan plainimage.

3. Pengubahan size cipherimage sangat berpengaruh terhadap gagalnya proses dekripsi. 


\section{DAFTAR PUSTAKA}

SETYANINGSIH, E. 2009. Penyandian Citra Menggunakan Metode Playfair Cipher, J. Teknol., vol. 2, no. 2, pp. 213-219.

ZEBUA, T. 2013. Analisa dan Implementasi Algoritma Triangle Chain pada Penyandian Record Database. Pelita Inform. Budi Darma, vol. 3, no. 2, pp. 37-49.

HENDARSYAH, D. \& WARDOYO, R. 2011. Implementasi Protokol Diffie-Hellman dan Algoritma RC4 untuk Keamanan Pesan SMS. IJCCS, vol. 5, no. 1, pp. 14-25.

MUNIR, R. 2004. Pengolahan Citra Digital dengan Pendekatan Algoritmik. Bandung: Informatika.

ARIYUS, D. 2008. Pengantar Ilmu Kriptografi, Yogyakarta: Andi.

ZEBUA, T. 2015. Penerapan Metode LSB-2 untuk Menyembunyikan Ciphertext pada Citra Digital. Pelita Inform. Budi Darma, vol. 10, no. 3, pp. 135-140.

SETIANINGSIH, E. 2015. Kriptografi dan Implementasi Menggunakan Matlab, Yagyakarta: Andi.

AGUNG, H. \& BUDIMAN. 2015. Implementasi Affine Chiper dan RC4 Pada Enkripsi File Tunggal. Prosiding SNATIF, pp. 243-250.

HAJI, W. H. \& MULYONO, S. 2012. Implementasi Rc4 Stream Cipher Untuk Keamanan Basis Data. Seminar Nasional Aplikasi Teknologi Informasi (SNATI). pp. 15-16. 